\title{
An Integrated Wireline-Log and Biostratigraphic Appraisal of Olure-1 and Abigboro-1 Wells, Onshore Niger Delta
}

\author{
Olugbenga A. Boboye ${ }^{1}$, Abdulkarim S. Oladayo', Emmanuel E. Okon ${ }^{2}$ \\ ${ }^{1}$ Department of Geology, University of Ibadan, Ibadan, Nigeria \\ ${ }^{2}$ Department of Geology, University of Calabar, Calabar, Nigeria \\ Email: boboyegbenga@yahoo.com, etyboy911@yahoo.com
}

How to cite this paper: Boboye, O.A., Oladayo, A.S. and Okon, E.E. (2017) An Integrated Wireline-Log and Biostratigraphic Appraisal of Olure-1 and Abigboro-1 Wells, Onshore Niger Delta. Open Journal of Geology, 7, 1140-1159.

https://doi.org/10.4236/ojg.2017.78076

Received: June 13, 2017

Accepted: August 14, 2017

Published: August 17, 2017

Copyright $(9) 2017$ by authors and Scientific Research Publishing Inc. This work is licensed under the Creative Commons Attribution International License (CC BY 4.0).

http://creativecommons.org/licenses/by/4.0/

\section{c) (i) Open Access}

\begin{abstract}
Studies of two wells within the coastal swamp onshore Niger Delta were carried out in order to determine the chronology, biozonation, and establishment of sequence stratigraphic framework for the representative wells. A total of twenty-eight (28) cutting samples were recovered and analysed from Abigboro-1 and Olure-1 exploratory wells for their foraminifera, calcareous nannofossils and palynomorphs' compositions. The results indicated the presence of diverse species within the wells, which include Lenticulina grandis, Florilus ex. gr. costiferum, Hanzawaia concentrica, Hopkinsina bononiensis, Marginulina costata and pseudonodosaria sp., Bolivina mandoroveensis, Eponides eshira, Lenticulina grandis, Lenticulina grandis, Cibicorbis inflata, Heterolepa floridana, Florilus ex. gr scaphum, Poroeponides lateralis, Uvigerina sparsicostata, Uvigerina subperegrina, Bolivina ex. gr. scalptrata, Valvulineria sp. and Epistominella pacifica. An inner neritic (1694 m - $2161 \mathrm{~m})$, coastal deltaic $(1557 \mathrm{~m}-1640 \mathrm{~m})$ and shallow inner neritic $(1347 \mathrm{~m}-1554 \mathrm{~m})$ palaeoenvironment was suggested for Olure-1 well while a broad grouping of the intervals as inner to middle neritic was suggested for Abigboro-1 well. The ratio of species abundance/diversity and integration of log suite data predicted two Maximum Flooding Surfaces (MFS) and one Sequence Boundary (SB) for Olure-1 well. The MFS were encountered at depths $2728 \mathrm{~m}$ (MFS 1) and 1797 $\mathrm{m}$ (MFS 2), while the SB was predicted at depth $2602 \mathrm{~m}$ (SB1). Diverse systems' tracts were identified and delineated from wireline logs of Olure-1 well and the implication for petroleum exploration was discussed. Late Oligocene early Miocene age has been assigned for the wells based on the recovered diagnostic species.
\end{abstract}

\section{Keywords}

Species, Palaeoenvironment, Palynomorphs, Nannofossil, Biozonation 


\section{Introduction}

The Niger Delta is situated in the Gulf of Guinea and extends throughout the Niger Delta province [1] (Figure 1). From Eocene to Present, the delta has prograded south-westward, forming depobelts that represent the most active portion of the delta at each stage of its development [2]. These depobelts form one of the largest regressive deltas in the world with an area of $300,000 \mathrm{~km}^{2}$ [3], sediment volume of $500,000 \mathrm{~km}^{3}$ and a sediment thickness of over $10 \mathrm{~km}$ in the basin depocenter. The Niger Delta has been identified as an important sedimentary basin in Nigeria because of its reputation as one of the most prolific oil and gas provinces in the world, and it is known to contain one identified petroleum system [3] [4]. With increasing exploration and exploitation of hydrocarbon in the Niger Delta, which in turn has made the search for oil and gas increasingly difficult, it has become pertinent to acquire knowledge and expertise in order to improve geological research and technology to field development and production of this vast hydrocarbon resource. This however has necessitated re-evaluation via the concept of high resolution biostratigraphy and sequence stratigraphy of the basin in order to obtain a clearer resolution of the subsurface stratigraphy of the Niger Delta sedimentary basin. This is made possible by the integration of biostratigraphic, seismic and wireline log data. For each of these data, a sequence stratigraphic model is developed via unconformity bounding surfaces, flooding

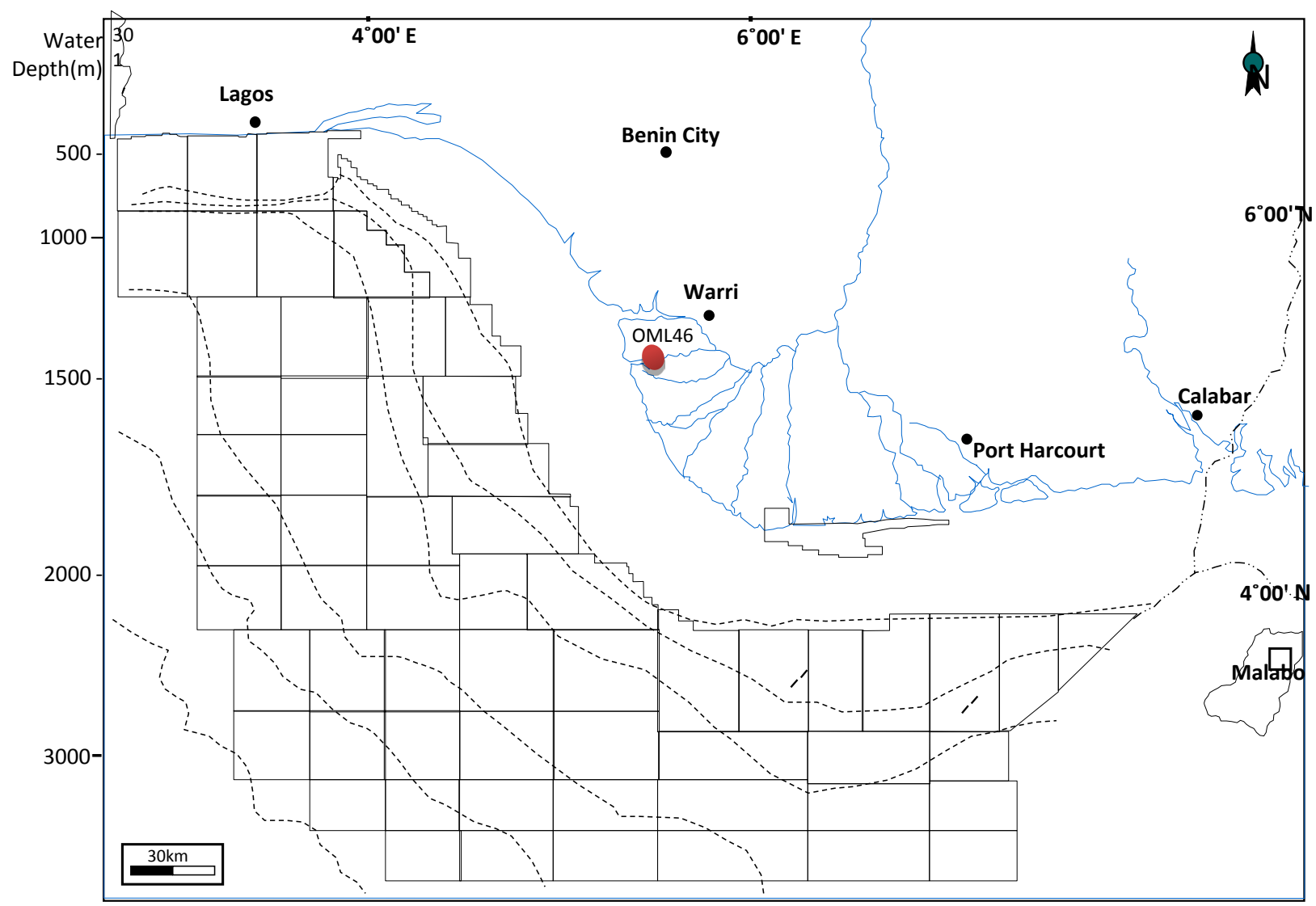

Figure 1. Map of Niger delta showing the location of studied area within OML 46. 
surfaces and systems tracts within sequence(s) and comparison of results is made across diverse data sets for accuracy and precision.

\section{Location of the Study Area}

The Niger Delta oil province of Nigeria is located on the southernmost end of Nigeria on the West African Continental margin. The study area is located onshore within OML 46. The basin lies between longitude $3^{\circ} \mathrm{E}$ and $9^{\circ} \mathrm{E}$ and latitude $4^{\circ} \mathrm{E}$ and $5^{\circ} 2^{\prime} \mathrm{N}$ (Figure 1 ).

\section{Previous Work}

The geology of Niger Delta in terms of age determination, depositional environment and biostratigraphic zonation has been discussed by many authors amongst which are Clement et al. [5] who reported the sequence stratigraphic study of "UNIABR Field" in northern delta depobelt of Niger Delta, and were able to identify five maximum flooding surfaces (MFS) and five sequence boundaries (SB) in which their average depths were tied to their absolute ages. Late Eocene to early Miocene age was proposed for the studied area based on palynological zonation. Oloto and Promise reported on biostratigraphic study and palaeoenvironmental reconstruction indicated early-middle Miocene age for Bongo ST-1, Ngolo and Opukushi-25 wells [6]. Early Miocene was proposed for Bongo-4 well based on the First Appearance Datum (FAD) and Last Appearance Datum (LAD) of diagnostic fauna and flora of Globorotalia obesa, Globigerinoides bisphericus, G. obliguus, Globigerinoides immaturus, Orbulina universa and Orbolina suturalis. The suite of early-middle Miocene benthic foraminiferal assemblage recovered include Bolivina miocenia, Lenticulina rotulata, Alveolephragmium crassium, Bolivina beyrichi, Saccammina complanata and Cyclammina minima. Also establish was the depositional environment and palaeobathymetry of the studied wells based on depth diagnostic benthics, floral and associated accessories like glauconite, mica, faecal pellets foraminiferal test linings, pediastrum and fungal spores within each wells. The depositional environment established range from marginal marine to shallow marine (littoral-middle neritic), corresponding to onshore to offshore within the continental plain to the continental shelf. Two microfossil biozones of Cyclammina minima and Haplophragmoides narivaensis have been established in the Oborduka-1 well, deep offshore of Niger Delta [7]. They assigned late Miocene age and a nearshore and/or marginal marine environment for the sediments based on the recovered fauna and flora assemblages. Boboye and Adeleye documented the high resolution biostratigraphy of some early Pliocene-late Miocene strata using calcareous nannoplankton and foraminiferal of the deep offshore Niger Delta area of Nigeria. Four condensed sections for the foraminiferal assemblages and four zones for the calcareous nannofossils as correlated to the Global Cycle Chart (NN 13, NN 11, NN 10 and NN 9) were established [8]. A tentative sequence stratigraphy framework was proposed and dated the Maximum Flooding 
Surfaces as early Pliocene to late Miocene which was associated with the 5.0 $\mathrm{Ma}$, 7.4 Ma, 8.6 Ma and 9.2 Ma. Van Hoeken-Klinkenbers palynological studies on boreholes samples in the western part of the Niger Delta concluded a Palaeogene age in some part of the Niger Delta exhibiting poor palynomorphs preservation [9]. A continuous temperature-climate optimum was demonstrated for the development of Globigerina bulloides and tropical climate for the development of Globorotalia foshi [10]. It was concluded that Tertiary fauna provinces were distributed asymmetrically about the equator probably by major ocean currents. Ozumba and Amajor reported a high resolution foraminiferal biostratigraphy of four wells (Kanbo-5, Egbedicreek-1, Angalalli-1 and Opukushi-5) located in the coastal and central swamp in the western Niger Delta [11]. They defined six foraminiferal zones (Assemblage/Partial range zones) for the middle to late Miocene Niger Delta namely: Globigerina cf ciperoensis Zone, Nonion centrosulcatum/Chiloguembelina victoria Zone, Eponides eshira Zone, Uvigerina sparsicostata Zone, Spirosigmoilina oligoceanica Zone, and Florilus ex. gr. costiferum Zone. The advantages of calcareous nannofossils in the recognition of marine flooding surfaces in the Niger Delta most especially in the late Miocene to late Pliocene time was discussed and recognized four delta wide flooding surfaces based on the Discoaster quinqueramus, Ceratholithus species and Gephyrocapsa species and Sphenolithus species. This corroborated the influx of Sphenolithus abies in the late Miocene of the Niger Delta [12].

\section{Materials and Methodology}

Data used in this study include log suites data and cuttings from two exploratory wells (Olure-1 and Abigboro-1) in Niger Delta. Systematic logging and detailed analysis and interpretation of the well logs, preparation and analyses for the fauna and flora contents were carried out. These were integrated to generate a sequence stratigraphic framework for the selected wells. The biostratigraphic analysis was carried out while the other analyses were achieved using Petrel and STRATABUG softwares.

\section{Biostratigraphy Preparations}

These cuttings were prepared for calcareous nannofosils, sporomorphs and foraminifera contents using standard preparatory techniques;

The calcareous nannofossil analysis involves the standard simple smear preparation technique of Perch-Nielsen [13]. About $5 \mathrm{~g}$ of the sample was gently crushed and dispersed in distilled water in a glass vial. It was dried at $50^{\circ} \mathrm{C}$ and mounted on a glass slide with the Norland adhesive mounting medium. Species were identified using relevant reference slides, Chevron and Shell (SPDC) albums.

For the foraminiferal preparation, about $25 \mathrm{~g}$ of the sample were soaked in $\mathrm{NaOH}$ solution for 24 hours to ensure proper disaggregation of the samples and the liberation of any foraminifera or micro-fauna accessories within the cuttings. 
The samples were then washed using a 63 micron sieve under a jet running water. The samples were then dried in an oven at $80^{\circ} \mathrm{C}$.

The palynomorph analysis entails the addition of Hydrofluoric acid (HF) and was then treated with $10 \%$ hydrochloric acid in a fume cupboard to remove carbonates. $10 \% \mathrm{HCl}$ solution was then added and heated for 25 to 30 minutes. The samples were decanted thrice at an interval of 1 hour each through the Branson Sonifer, with the aid of 5 micron sieve to filter away the inorganic matter. The retrieved organic matter was stained with Safranin solution for easy identification of the dinocyst that are almost totally transparent. The Loctite impruv is used for permanent mounting of the slides. The slides were studied under a binocular light microscope and the identification was done via reference slides of Chevron and Shell albums.

\section{Results and Discussion}

The results showed that the biostratigraphy of Olure-1 and Abigboro-1 wells have fairly good microfossil recovery except for Abigboro-1 well which is barren in foraminifera and calcareous nannofossils (Figures 2-10 and Tables 1-5).

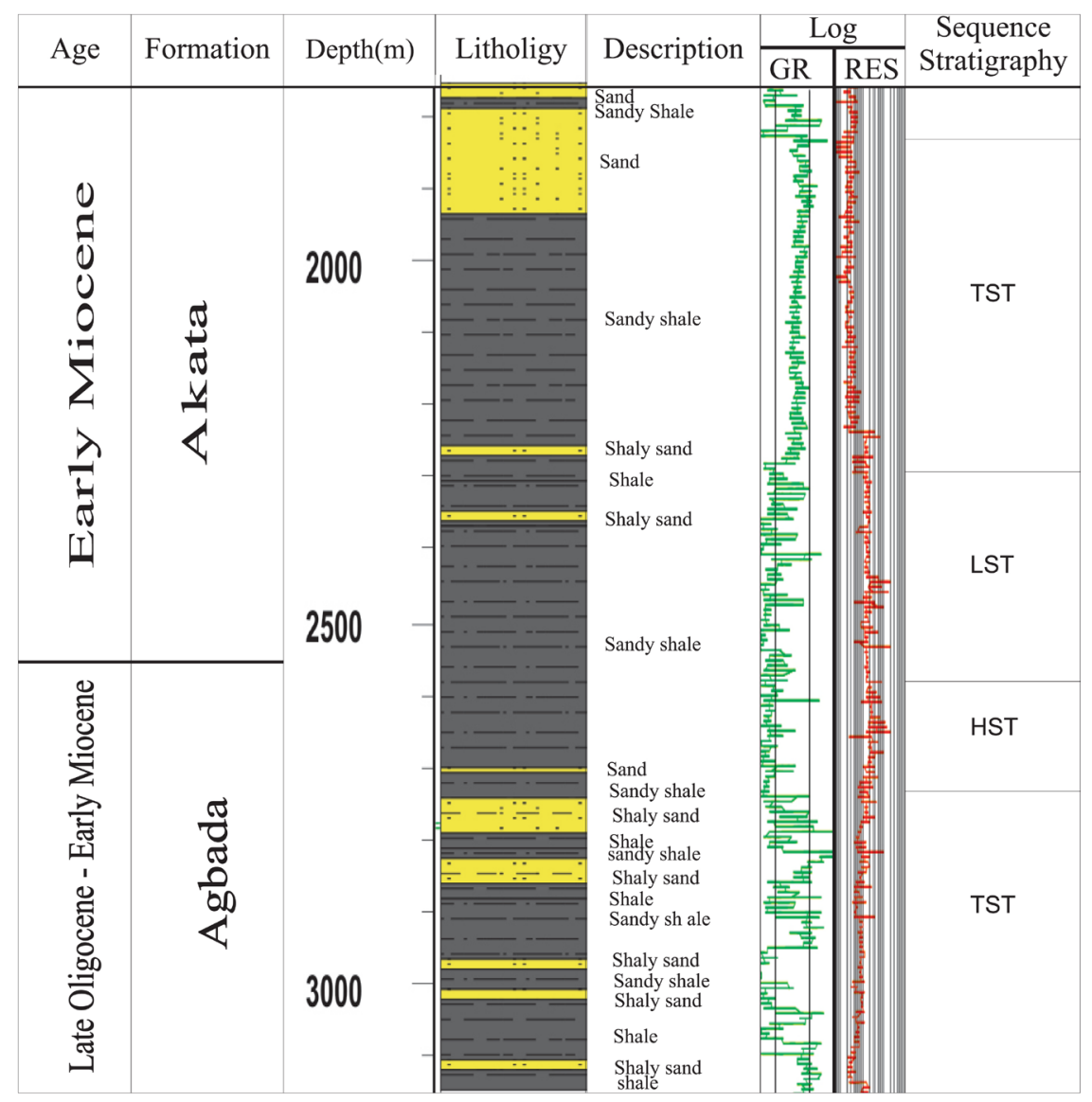

Figure 2. Lithologic section and sequence stratigraphic framework of the Olure-1 well. LST-Lowstand Systems Tract, TST-Transgressive Systems Tract, HST-Highstand Systems Tract. 
Table 1. (a) Abundance and diversity of pollen and spores and (b) planktonic and calcareous foraminifera in Olure-1 well.

(a)

\begin{tabular}{ccccc}
\hline \multirow{2}{*}{ Depth $(\mathrm{m})$} & \multicolumn{2}{c}{ Spores } & \multicolumn{2}{c}{ Pollen } \\
\cline { 2 - 5 } & Abundance & Diversity & Abundance & Diversity \\
\hline 1664 & 20 & 3 & 35 & 3 \\
1756 & 16 & 6 & 20 & 3 \\
1975 & 30 & 4 & 48 & 9 \\
2304 & 38 & 5 & 51 & 12 \\
2487 & 45 & 4 & 51 & 10 \\
2633 & 14 & 5 & 22 & 8 \\
2652 & 18 & 5 & 28 & 8 \\
2761 & 11 & 2 & 19 & 10 \\
2981 & 30 & 5 & 24 & 6 \\
3182 & 37 & 5 & 37 & 10 \\
\hline
\end{tabular}

(b)

\begin{tabular}{ccccc}
\hline \multirow{2}{*}{ Depth $(\mathrm{m})$} & \multicolumn{2}{c}{ Planktonic foraminifera } & \multicolumn{2}{c}{ Calcareous foraminifera } \\
\cline { 2 - 5 } & Abundance & Diversity & Abundance & Diversity \\
\hline 1664 & - & - & - & - \\
1756 & - & - & 1 & 1 \\
1975 & - & - & 29 & 7 \\
2304 & - & - & 52 & 10 \\
2487 & - & - & 47 & 9 \\
2633 & 2 & 2 & 42 & 8 \\
2652 & 1 & 1 & 174 & 12 \\
2761 & 3 & 2 & 3 & 2 \\
2981 & - & - & 1 & 1 \\
3182 & - & - & 3 & 2 \\
\hline
\end{tabular}

Table 2. The abundance and diversity of calcareous nannofossils (Olure-1 well).

\begin{tabular}{ccc}
\hline Depth $(\mathrm{m})$ & Abundance & Diversity \\
\hline 1664 & - & - \\
1756 & - & - \\
1975 & 8 & 6 \\
2304 & 1 & 1 \\
2487 & & - \\
2633 & 1 & 1 \\
2652 & 4 & 2 \\
2761 & - & - \\
2981 & - & - \\
3182 & - & - \\
\hline
\end{tabular}




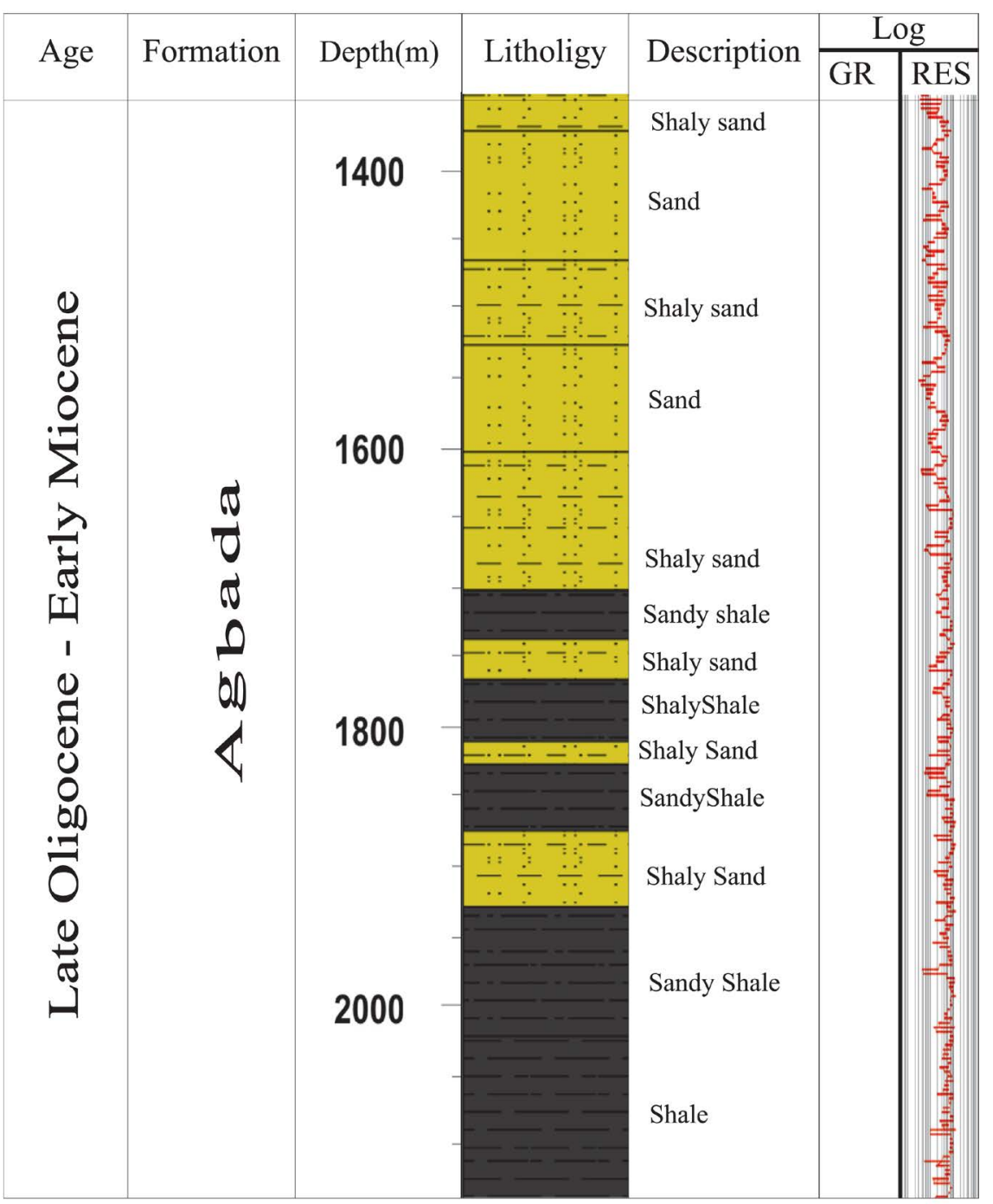

Figure 3. Lithologic section of the Abigboro-1 well. LST-Lowstand Systems Tract, TSTTransgressive Systems Tract, HST-Highstand Systems Tract.

Table 3. Total abundance of palynomorphs and foraminiferal assemblages for Olure-1 well.

\begin{tabular}{ccccccc}
\hline Depth $(\mathrm{m})$ & $\begin{array}{c}\text { Abundance } \\
\text { of spores }\end{array}$ & $\begin{array}{c}\text { Abundance } \\
\text { of pollen }\end{array}$ & Total & $\begin{array}{c}\text { Abundance of } \\
\text { planktonic } \\
\text { foraminifera }\end{array}$ & $\begin{array}{c}\text { Abundance } \\
\text { of calcareous } \\
\text { foraminifera }\end{array}$ & Total \\
\hline 1664 & 20 & 35 & 55 & - & - & 0 \\
1756 & 16 & 20 & 36 & - & 1 & 1 \\
1975 & 30 & 48 & 78 & - & 29 & 29 \\
2304 & 38 & 51 & 89 & - & 52 & 52 \\
2487 & 45 & 51 & 96 & - & 47 & 47 \\
2633 & 14 & 22 & 36 & 2 & 42 & 44 \\
2652 & 18 & 28 & 46 & 1 & 174 & 175 \\
2761 & 11 & 19 & 30 & 3 & 3 & 6 \\
2981 & 30 & 24 & 54 & - & 1 & 1 \\
3182 & 37 & 37 & 74 & - & 3 & 3 \\
\hline
\end{tabular}


O. A. Boboye et al.

Table 4. Total diversity of palynomorphs and for aminiferal assemblages for Olure-1 well.

\begin{tabular}{ccccccc}
\hline Depth (m) & $\begin{array}{c}\text { Diversity } \\
\text { of spores }\end{array}$ & $\begin{array}{c}\text { Diversity } \\
\text { of pollen }\end{array}$ & Total & $\begin{array}{c}\text { Diversity of } \\
\text { planktonic } \\
\text { foraminifera }\end{array}$ & $\begin{array}{c}\text { Diversity of } \\
\text { calcareous } \\
\text { foraminifera }\end{array}$ & Total \\
\hline 1664 & 3 & 3 & 6 & - & - & 0 \\
1756 & 6 & 3 & 9 & - & 1 & 1 \\
1975 & 4 & 9 & 13 & - & 7 & 7 \\
2304 & 5 & 12 & 17 & - & 10 & 10 \\
2487 & 4 & 10 & 14 & - & 9 & 9 \\
2633 & 5 & 8 & 13 & 2 & 1 & 10 \\
2652 & 5 & 8 & 13 & 1 & 2 & 13 \\
2761 & 2 & 10 & 12 & 2 & 1 & 4 \\
2981 & 5 & 6 & 11 & - & 2 & 2 \\
3182 & 5 & 10 & 15 & - & & 2 \\
\hline
\end{tabular}

Table 5. Abundance and diversity of pollen and spores in Abigboro-1 well.

\begin{tabular}{|c|c|c|c|c|}
\hline \multirow{2}{*}{ Depth (m) } & \multicolumn{2}{|c|}{ Spores } & \multicolumn{2}{|c|}{ Pollen } \\
\hline & Abundance & Diversity & Abundance & Diversity \\
\hline 1356 & 29 & 5 & 22 & 7 \\
\hline 1676 & 261 & 8 & 242 & 16 \\
\hline 1713 & 283 & 7 & 271 & 14 \\
\hline 1722 & 275 & 5 & 33 & 17 \\
\hline 1731 & 244 & 6 & 19 & 15 \\
\hline 1750 & 269 & 6 & 19 & 14 \\
\hline 1788 & 371 & 6 & 183 & 16 \\
\hline 1850 & 152 & 4 & 79 & 5 \\
\hline 1923 & 119 & 3 & 118 & 9 \\
\hline 1942 & 289 & 4 & 113 & 15 \\
\hline 1960 & 22 & 3 & 13 & 5 \\
\hline 1996 & 25 & 4 & 34 & 7 \\
\hline 2033 & 22 & 3 & 10 & 6 \\
\hline 2070 & 17 & 4 & 28 & 5 \\
\hline 2115 & 298 & 3 & 132 & 14 \\
\hline 2134 & 296 & 6 & 261 & 14 \\
\hline 2143 & 268 & 5 & 98 & 9 \\
\hline 2161 & 89 & 3 & 77 & 10 \\
\hline
\end{tabular}




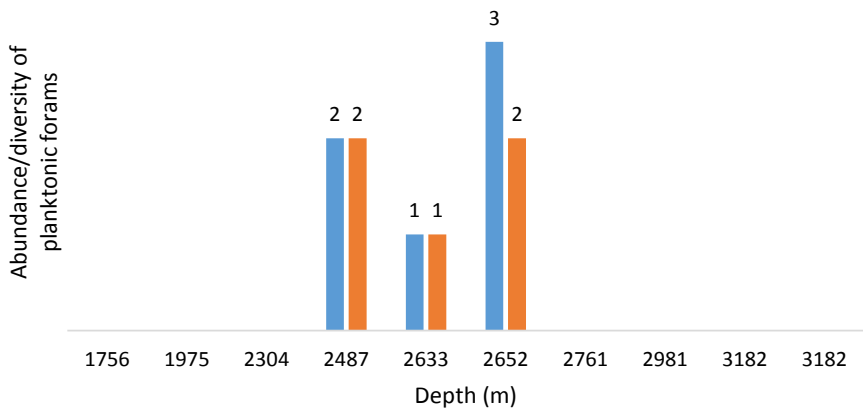

Abundance

diversity

(a)

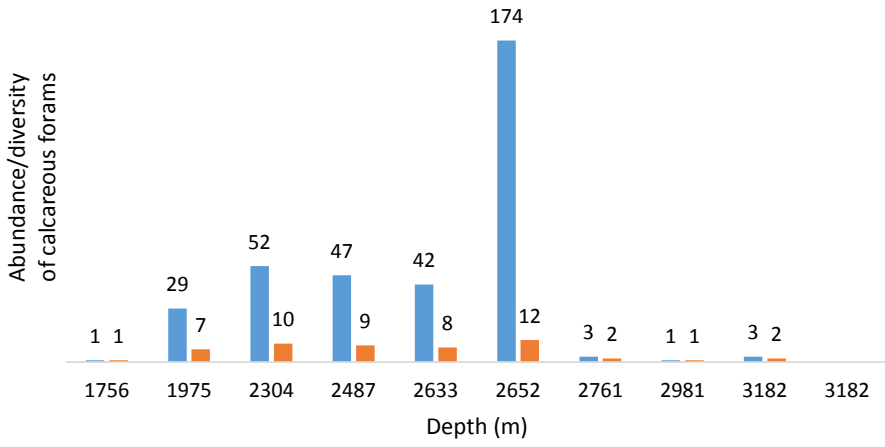

Abundance

diversity

(b)

Figure 4. Plots of abundance/diversity of planktonic and calcareous foraminifera against depth (Olure-1 well).

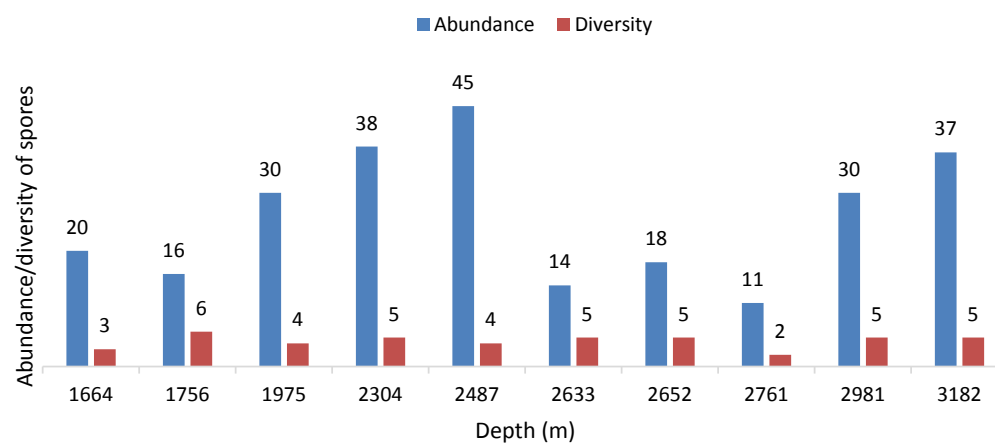

(a)

Abundance diversity

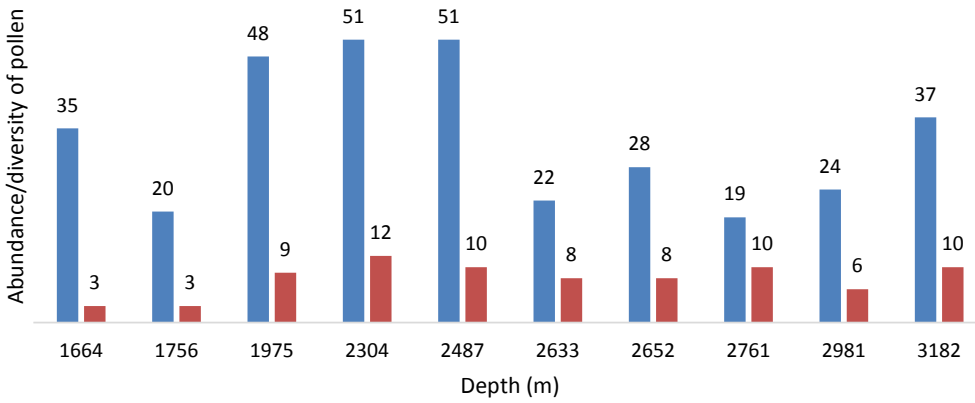

(b)

Figure 5. Plots of abundance/diversity of (a) Spores and (b) Pollen against depth (Olure1 well). 


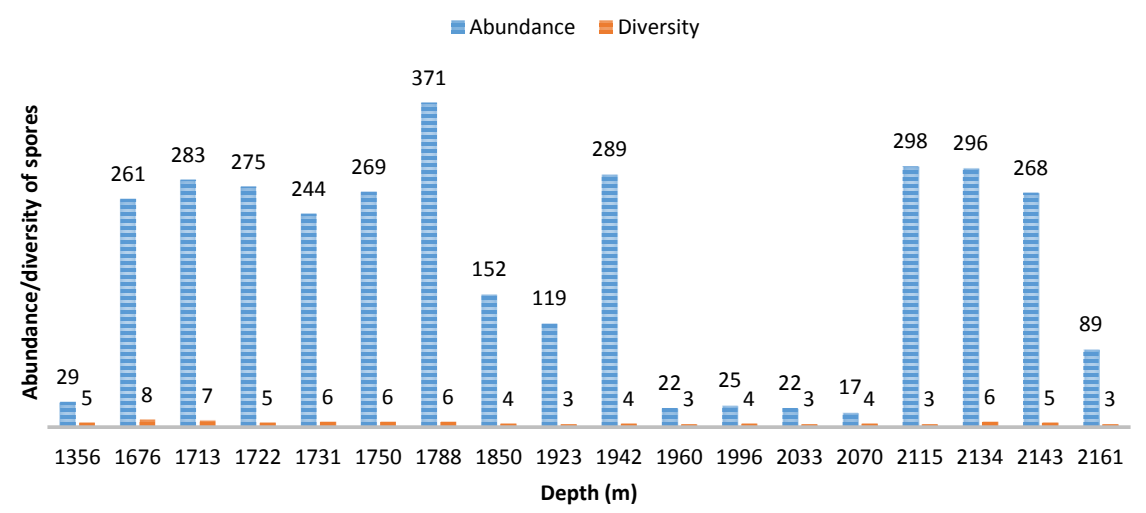

(a)

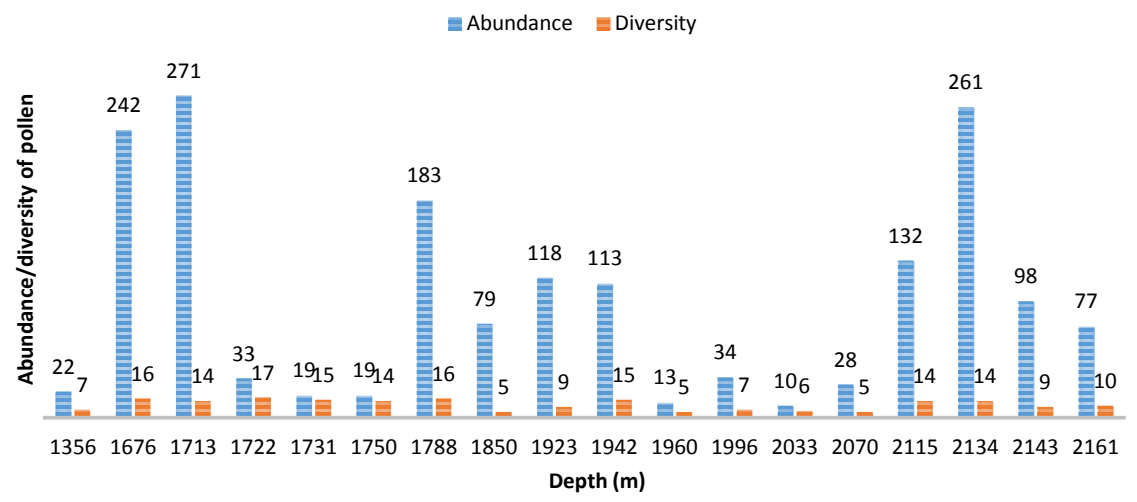

(b)

Figure 6. Plots of abundance/diversity of (a) Spores (b) Pollen against Depth (Abigboro-1 well).

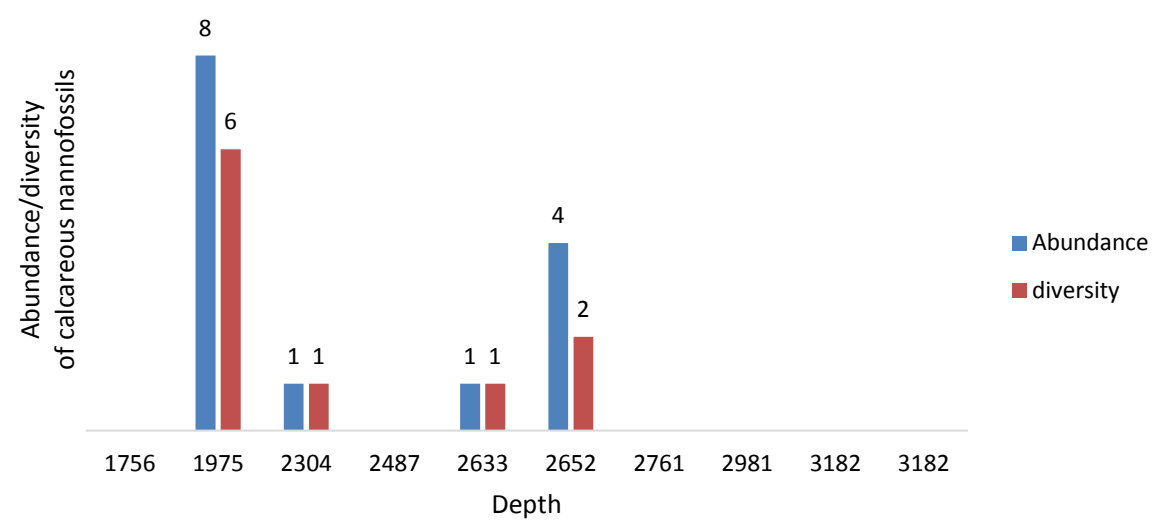

Figure 7. The abundance/diversity of calcareous nannofossils against depth (Olure-1 well).

\subsection{Lithostratigraphy}

Base on the available well log (gamma ray) and cutting samples, the Olure-1 and Abigboro-1 wells penetrated a total depth of $3182 \mathrm{~m}(10,440 \mathrm{ft})$ and $2161 \mathrm{~m}$ (7090 ft) depth respectively. The lithology constitutes a mixture of sand and shale units, with the shale occurring in significant amounts in an environment that is wholly marine and in variable proportion for a paralic depositional set- 


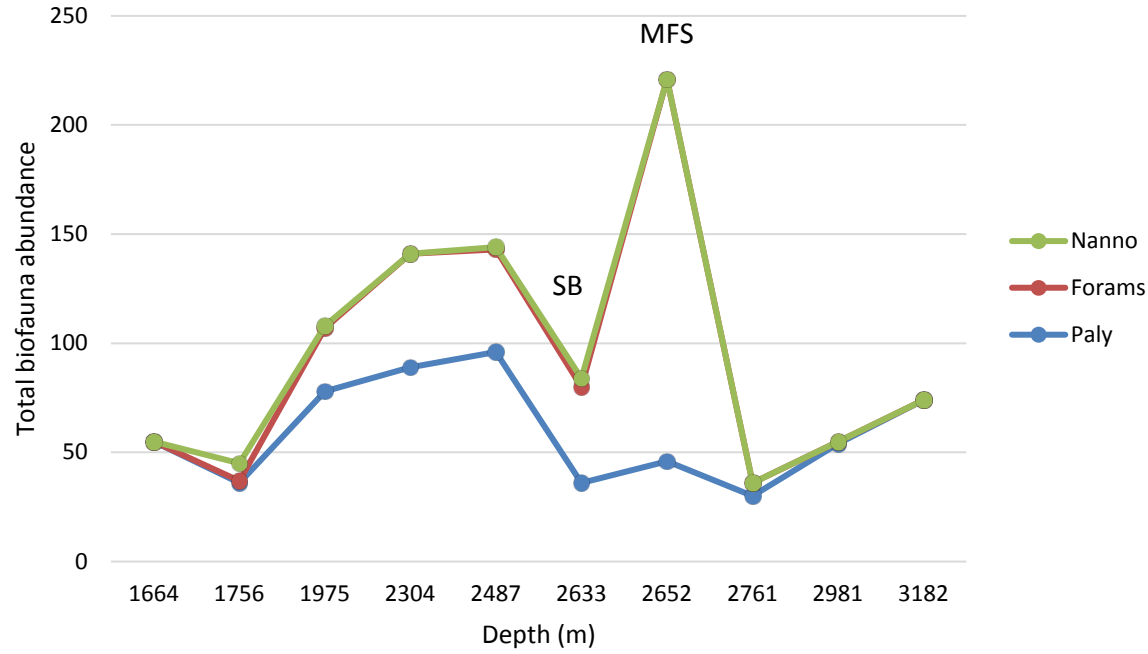

(a)

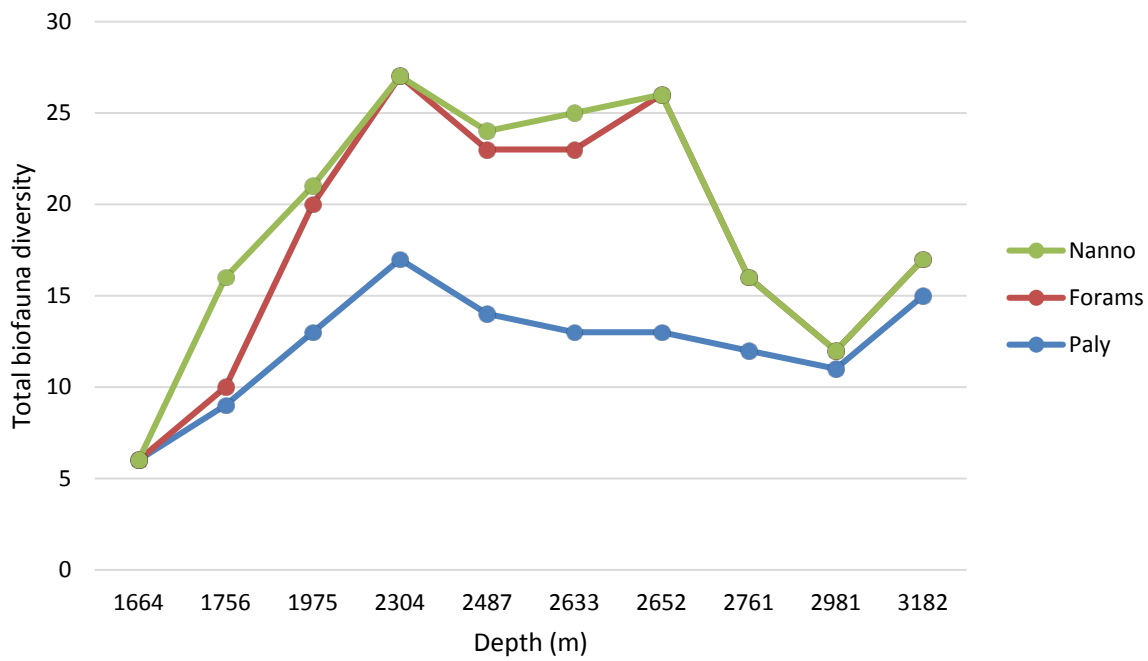

(b)

Figure 8. Plots of trend for: (a) biofauna total abundance and (b) total diversity against depth (Olure-1 well). ${ }^{*}$ Note: Nanno = calcareous nannofossil, Forams = foraminifera, Paly $=$ palynomorphs.

ting. This was simulated by the gamma ray log signature. A coarsening upward or fining upward unit within a forestepping or backstepping successions of the $\log$ pattern defines stacking patterns of genetic units. This aided the prediction of the positioning of maximum flooding surfaces, and the identification of the systems tracts when integrated with biostratigraphic data (Figure 2 and Figure 3).

\subsection{Biostratigraphy}

\section{Foraminifera study of the wells}

The biostratigraphic studies of the wells involved a total of eighteen (18) representative samples from $1347 \mathrm{~m}-2161 \mathrm{~m}$ intervals (Abigboro-1 well) and ten (10) representative samples from $1920 \mathrm{~m}-3182 \mathrm{~m}$ intervals (Olure-1 well) which 


\section{Calcareous nannofossils species}

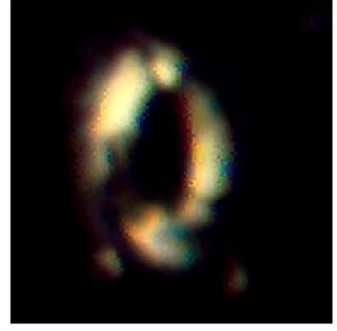

Helicosphaera ampliaperta

Foraminifera species

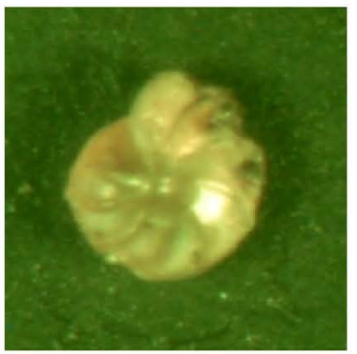

Lenticulina grandis Hopkinsina

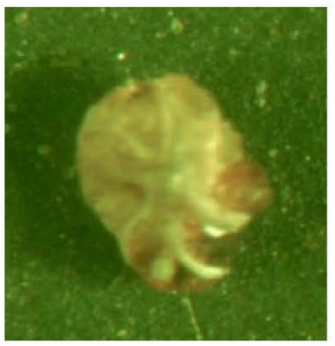

Eponides eshira

Palynomorphs species

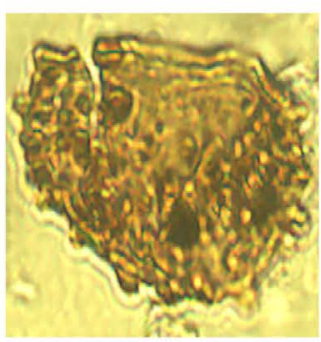

Verrucatosporite susmensis

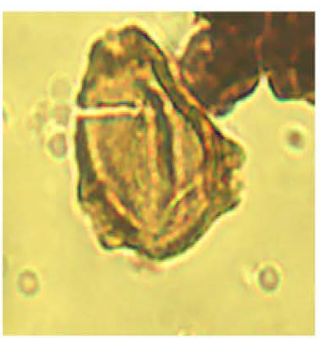

Retitricolporites irregularis

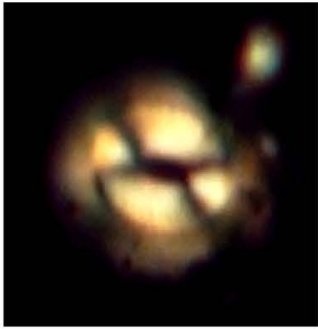

Coccolithus miopelagicus

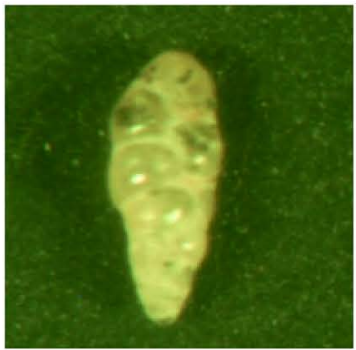

bononiensis Bolivina

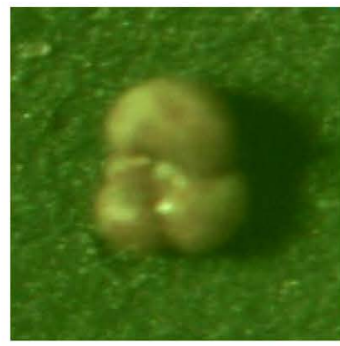

Globigderinoides primordius

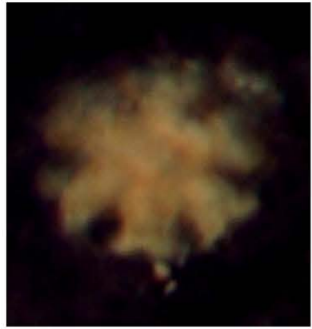

Magnification $\times 1250$

Discoaster deflandrei

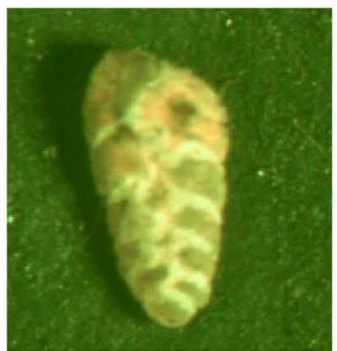

mandoroveensis

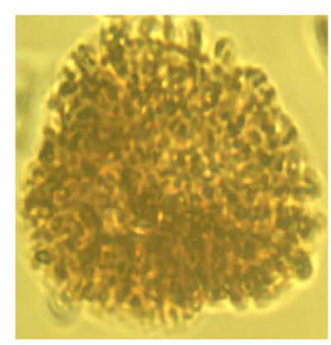

Retitricolporites irregularis

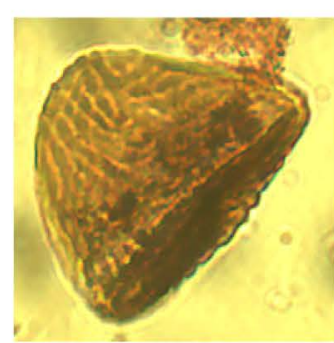

Cicatricosisporite dorogensis

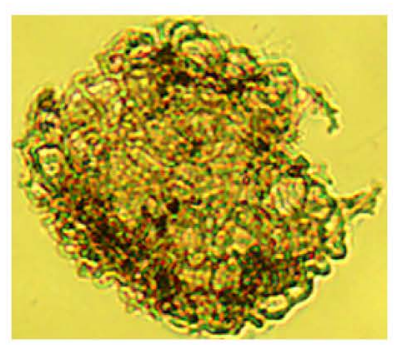

Praedapollis flexibilis

Figure 9. Photomicrograph of some selected diagnostic pollen and spores, calcareous nannofossils and foraminifera. 


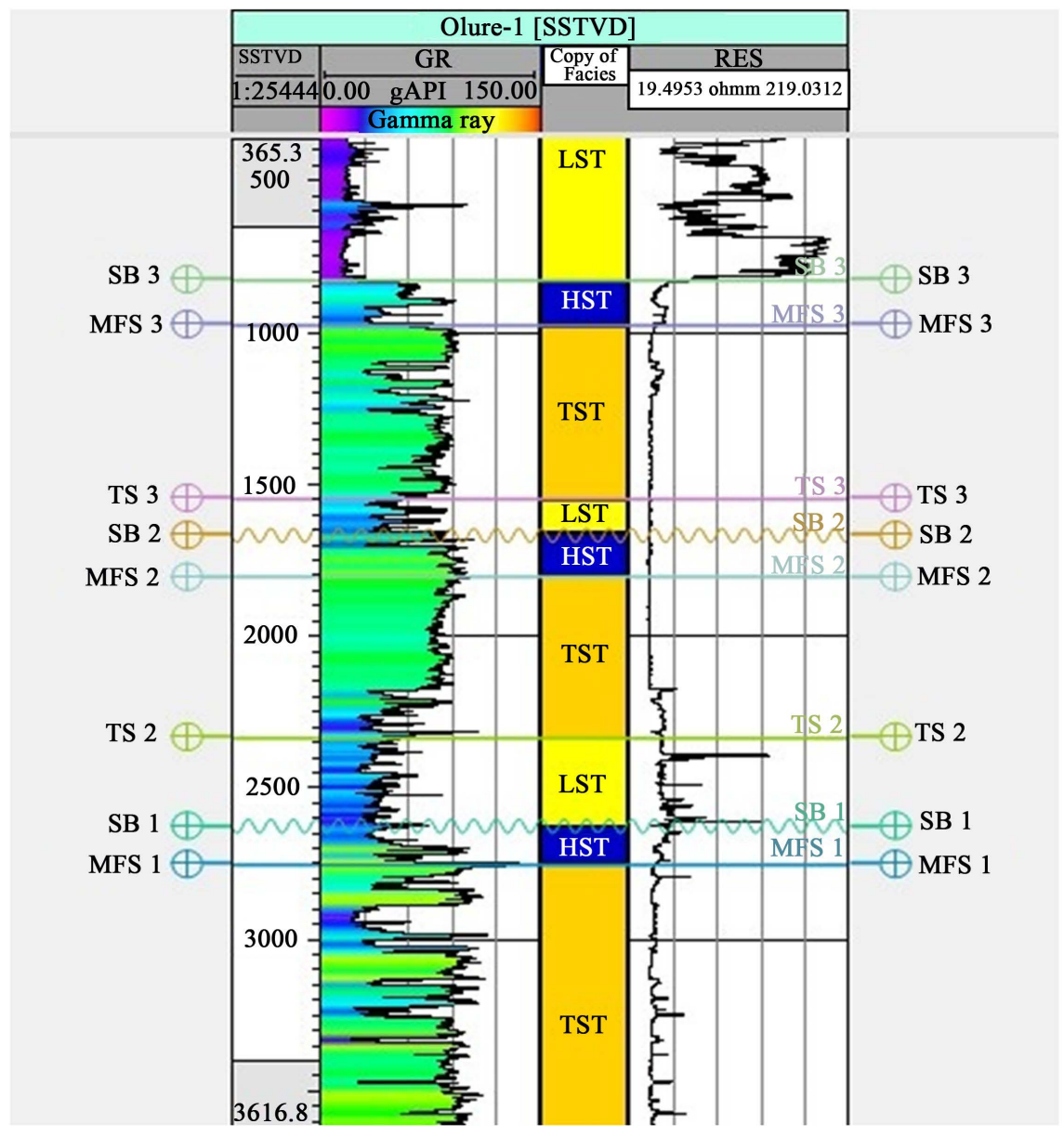

Figure 10. Wireline log of the key chronologic surfaces for the Olure-1 well.

were prepared and analysed for their microfossils. The foraminiferal recoveries in Abigboro-1 well within the studied sections are poor and the absence of planktic species precludes a refined zonal delineation for the analysed interval using the Blow planktic scheme [14] [15]. However on the basis of the recovered assemblages and the Niger Delta SPDC faunal zone scheme, the analysed intervals have been dated late Oligocene to early Miocene age corresponding to the N3 - N4 and F7800 - F9300 Zones for the two wells. The occurrence of Globigerinoides primordius at depth $2651 \mathrm{~m}$ within the Olure-1 well enabled the subdivision of the well section. The stratigraphic distributions of the recorded taxa are presented (Table 1, Table 3, Table 4 and Figure 4).

\subsection{Foraminiferal Biozonation}

The zonation of these study wells are based on the comparison of the recovered assemblages with that of the SPDC Niger Delta Faunal Zone;

\footnotetext{
Abigboro-1 Well

Interval: $2161 \mathrm{~m}-1347 \mathrm{~m}$

Zone: (N3 - N4)-Bolli and Saunders (1985)

Age: Late Oligocene to early Miocene
} 
Correlation: F7800 - F9300 (SPDC Faunal Zone)

Top: Placed at the first sample analysed at $1347 \mathrm{~m}$

Base: Placed at the base of the analysed section at $2161 \mathrm{~m}$

Description:

These intervals are characterized by rare and sporadic occurrences of foraminifera within $2060 \mathrm{~m}$ - $2069 \mathrm{~m}$ depths. The presence of Lenticulina grandis, Hopkinsina bononiensis and Bolivina mandoroveensis defined the assigned zones and ages. Other foraminifera found within the interval include Florilus ex. gr costiferum, Hanzawaia concetrica, Pseudonodosaria sp., Rotalia sp. and Marginulina costata.

Olure-1 Well

Interval: $1920 \mathrm{~m}$ - $2651 \mathrm{~m}$

Zone: (N4)-Bolli and Saunders [16]

Age: Early Miocene

Correlation: F9300 (SPDC Faunal Zone)

Top: Placed at the first sample analysed at $1347 \mathrm{~m}$

Base: Placed at the base of Globigerinoides primordius at $2651 \mathrm{~m}$.

\section{Description:}

This interval is characterized by rare and sporadic occurrences of foraminifera except at $2651 \mathrm{~m}$ depth. This lower interval was delineated based on the Last Downhole Occurrence of Globigerinoides primordius at $2651 \mathrm{~m}$ depth and it is taken as the zonal boundary marker between N4 and N3 Zones and consequently the late Oligocene/early Miocene boundary. The benthic assemblages present within the interval include Bolivina mandoroveensis, Eponides eshira, Hopkinsina bononiensis and Lenticulina grandis. Other foraminifera found within the interval include Bolivina ex. gr. scalptrata, Buliminella sp., Cibicorbis inflata, Heterolepa floridana, Florilus ex. gr scaphum, Poroeponides lateralis, Uvigerina peregrina, Uvigerina sparsicostata, Uvigerina subperegrina, Valvulineria sp. and Epistominella pacifica.

Interval: $2633 \mathrm{~m}-3182 \mathrm{~m}$

Zone: (N3)-Bolli and Saunders [16]

Age: Late Oligocene

Correlation: F7800 (SPDC Faunal Zone)

Top: Placed at the Last Downhole Occurrence of Globigerinoides primordius at $2633 \mathrm{~m}$.

Base: Placed at the last analysed sample at $3182 \mathrm{~m}$.

\section{Description:}

This interval is characterized by fairly abundant and diverse foraminifera. The interval was delineated based on the presence of the Last Downhole Occurrence (LDO) of Globigerinoides primordius at depth $2651 \mathrm{~m}$. The taxon's LDO has been consistently used to indicate the boundary between the N4 and N3 Zones and consequently the late Oligocene/early Miocene boundary. The benthic assemblages present within the interval include Bolivina mandoroveensis, Epon- 
ides eshira, Lenticulina grandis and Lenticulina grandis. Other foraminifera found within the interval include Bolivina ex. gr. scalptrata, Cibicorbis inflata, Heterolepa floridana, Florilus ex. gr scaphum, Poroeponides lateralis, Uvigerina sparsicostata, Uvigerina subperegrina, Valvulineria sp. and Epistominella pacifica.

Palynological study of the wells

A detailed palynological study was carried out on systematically selected eighteen (18) cutting samples from Abigboro-1 well at different intervals. The analysed intervals contain well preserved and abundant pollen, spores, fungal spores and dinoflagellate cysts. The recovered palynomorphs include abundant land derived forms such as Retibrevitricolporites protrudens, Retitricolporites irregularies, racemonocolpites hians, Arecipites exilimuratus, Psilatricolporites crassus, Praedapollis flexibilis, Gemmamonoporites sp., Laerigatosporites sp, Verrucatosporites usmansis, Verrucatosporites sp., Pteris sp., and Acrostictrum aureum. Moderate numbers of dinoflagellate cysts particularly Lingulodinium machaerophorum, Spiniferites sp., Homotryblium sp., Homotryblium pallidum, Polysphaeridium zoharyi, Leposphaeridia and Hystricholcolpona sp. which are indicative of a marine depositional environment were also recovered (Table 1 and Figure 5 and Figure 6).

\subsection{Palynological Biozonation}

This well falls within the broad Pan Tropical Magnastriatites howardi Zone of Germeraad et al. [17] and the P500 Zone of Evamy et al. [18]. Only the P560 and P540 Subzones were identified within the P500 Zone;

Zone P500

Subzone P560

Interval: $1347 \mathrm{~m}-1749 \mathrm{~m}$

Age: Middle Oligocene

Description

The top of this subzone is placed at $1347 \mathrm{~m}$ and the base is defined by the increased occurrence of Retibrevitricolporites protrudens at $1749 \mathrm{~m}$. This subzone corroborated with the abundant records of $R$. protrudens, Verrucatosporites usmensis, Praedapollis flexibilis, and Pteris sp.

Subzone P540

Interval: $1749 \mathrm{~m}-2161 \mathrm{~m}$

Age: Middle Oligocene

\section{Description}

The top of this subzone is placed at $1749 \mathrm{~m}$ and it is defined by the increased occurrence of Retibrevitricolporites protrudens. The base is placed at the depth of $2161 \mathrm{~m}$. This subzone is further characterized by the presence of Cicatricosisporites dorogensis, Gemmatriporites sp., Striamonocolpites rectostriatus, Arecipites exilimuratus and Grimsdalea poligonalis.

Calcareous nannofossil study of the wells 
This entails a total of ten (10) cuttings from interval $1920 \mathrm{~m}$ - $3182 \mathrm{~m}$ (Olure-1 well) and total of eighteen (18) cuttings selected from interval $1347 \mathrm{~m}-2161 \mathrm{~m}$ (Abigboro-1 well) were prepared and analysed for nannofossils at various intervals. The study revealed rare to few and scattered occurrences of nanno-fossils in Olure-1 well while intervals have been found to be barren of nannofossil occurrences in Abigboro-1 well. The occurrence of few index markers within the analysed section of Olure-1 well facilitated the subdivision of the well sections into zones based on the zonation scheme of Martini [19]. Interval $1920 \mathrm{~m}-2633 \mathrm{~m}$ has been dated early Miocene (NN2 - NN4 Zones) while interval 2633 m - 3182 $\mathrm{m}$ is believed to be of late Oligocene to early Miocene (NP24 - NN1 Zones) (Table 2 and Figure 7).

\subsection{Calcareous Nannofossil Biozonation}

The zonation scheme of Martini [19] was employed for the zonation of the wells;

Interval: $1920 \mathrm{~m}-2633 \mathrm{~m}$

Zone: NN4 - NN2

Top: Placed at the first sample analysed at $1920 \mathrm{~m}$

Base: Top Helicosphaera truempyi

Age: Early Miocene

Description:

This interval is characterized by rare to sparse occurrence of nannofossils. This interval has been delineated based on the presence of characteristic early Miocene (NN4 - NN2) taxa including Discoaster deflandrei, Coccolithus miopelagicus and Helicosphaera ampliaperta.

Interval: $2651 \mathrm{~m}-3182 \mathrm{~m}$

Zone: NN1 - NP24

Top: Top Helicosphaera truempyi

Base: Tentatively placed at the last analysed sample at $3182 \mathrm{~m}$

Age: Early Miocene to late Oligocene

\section{Description:}

This interval is characterized by very rare and sporadic occurrences of nannofossils. The occurrence of Helicosphaera truempyi at $2633 \mathrm{~m}$ depth is an indication that the well is not younger than the early Miocene NN1 Zone, while the other intervals stands for the total range (NN1 - NP24) of Helicosphaera truempyi Zonal marker.

\subsection{Sequence Stratigraphic Framework}

\section{Case Study Appraisal for Olure-1 Well}

This was based on the gamma ray and resistivity log signatures of the well. The key surfaces and systems tract were identified (Figure 10).

Sequence Boundary (SB) and Maximum Flooding Surface (MFS)

Three Maximum Flooding Surface (MFS) and Sequence Boundaries (SB) were identified respectively. These points corresponds to depths of $2728 \mathrm{~m}$ (MFS 1), 1797 (MFS 2), and 971 (MFS 3) for the Maximum Flooding Surfaces and $2602 \mathrm{~m}$ 
(SB 1), 1661 (SB 2), and 825 (SB 3) for Sequence Boundary (Figure 10). MFS 1 and MFS 2 and SB 1 correspond to intervals where we have the peak and least abundance of biofauna respectively.

Lowstand Systems Tract (LST)

From the log signatures, the LST is bounded at the base by SB 1, SB 2, and SB 3 and at the top by TS 1 , TS 2, and TS 3, showing the coarsening upward log motif. These system tracts represent sand packages that signify the basin floor fan, which is overlain by slope fan and capped by shaly lowstand wedge. The biostratigraphic study also showed progressive decrease in abundance and diversity of biofauna due to fall in water level and shallowing of the shore.

Transgressive Systems Tract (TST)

In Olure-1 well, the TST is bounded at the top by MFS 1, MFS 2, and MFS 3 and at the base by TS 1 , TS 2 , and TS 3 . The stacking pattern showed a finning upwards log motif. Also the parasequences within the TST backstep in a retrogradational parasequence set. The progressive increase in biofauna indicated progressive increase in water level and that the systems tract progressively deepens upward as successively younger parasequences step farther landward.

Highstand Systems Tract (HST)

The HST is bounded at the base by MFS 1, MFS 2, and MFS 3 and at the top by SB 1, SB 2, and SB 3. The early highstand consists of an aggradational parasequence set as evidenced on the log signatures. However, the late highstand is composed of one or more progradational parasequence sets (Figure 10). The biofauna trend for this systems tract shows a peak in abundance and diversity of species followed by a progressive decrease.

\subsection{Depositional Environment}

The depositional milieu of the study wells were determined based on the sedimentological and biostratigrapical inferences (Figure 8). Based on the foraminifera recovered from Olure-1 well, the environment was suggested to have been deposited within the inner neritic environment with the occurrence of Lenticulina grandis, Florilus ex. gr. costiferum, Hanzawaia concentrica, Hopkinsina bononiensis, Marginulina costata and pseudonodosaria sp. Within the interval of $1557 \mathrm{~m}-1640 \mathrm{~m}$ which is predominantly sandy lithofacies indicated a coastal deltaic environment while the shaly upper section within $1347 \mathrm{~m}$ - $1554 \mathrm{~m}$ suggested a shallow inner neritic environment with the presence of Lenticulina grandis at $1347 \mathrm{~m}-1356 \mathrm{~m}$ depth.

The recovered palynomorphs suggested a marine depositional environment with fresh water influx based on the occurrence of abundant land derived forms such as Racemonocolporites hians, Psilatricolporites crassus, Pachydermites diederixi, Retitricolporites irregularies, Laevigatosporites sp., Verrugatosporites sp., Acrostichum aureum and Pteris sp., as well as moderate numbers of dinoflagellate cysts which include Leiophaeridia sp., Lingulodinium Machaerophorum, Polysphaeridium zoharyi, Operculodinium centocarpum, spiniferites 
sp. Few marine indicators microforaminiferal wall linings with sparse occurrences of dinoflagellate cysts and fresh water algae Botryococcus brauni suggested a littoral-marine depositional environment. However, the benthic foraminifera distribution suggest a broad grouping of the intervals as inner to middle neritic based on characteristic depth indicator foraminfera recorded within the intervals. This include Bolivina mandoroveensis, Eponides eshira, Lenticulina grandis, Lenticulina grandis, Cibicorbis inflata, Heterolepa floridana, Florilus ex. gr scaphum, Poroeponides lateralis, Uvigerina sparsicostata, Uvigerina subperegrina, Bolivina ex. gr. scalptrata, Valvulineria sp. and Epistominella pacifica.

\subsection{Exploration Implication}

The application of sequence stratigraphic framework in the study wells have made prediction possible, the positioning of the key chronostratigraphic surfaces, such as flooding and erosional surfaces as well as the System Tracts (ST) and their parasequences stacking patterns. This allows for the identification of plays and potential prospect evaluations in exploration for oil and gas. The sequence stratigraphic study of the two wells indicated that the lowstand consist of sand packages that can serve as hydrocarbon reservoirs. It is suggested that during periods of lowering of the sea level, when the rate of sediment input far exceeded the subsidence rate (progradation), deposition of sandstone reservoir occurred in the form of incised valley fills, slope fan complexes and prograding complex within the lowstand wedges. As the sea level began to rise, the earlier formed reservoirs were sealed by the deposition of relatively organically rich shale prone sediments of the Transgressive Systems Tract (TST). This model produces a reservoir/seal relationship whereby hydrocarbon expelled by the organically rich lithofacies, upon maturation may be trapped within the sealed reservoir rocks either by structural, and/or stratigraphic trapping mechanism.

\section{Conclusions}

The integration of biostratigraphic data with wireline log data exemplified a sequence stratigraphic model to be generated for Olure-1 and Abigboro-1 wells. Lithologic description from logs and cutting samples indicated a mixture of sand and shale units. The various biostratigraphic plots for Olure-1 well show the presence of Maximum Flooding Surfaces at depth intervals $2304 \mathrm{~m}-2487 \mathrm{~m}$ and $2652 \mathrm{~m}$ - $2730 \mathrm{~m}$, while Abigboro-1 well shows the presence of Maximum Flooding Surfaces at depth range between $1750 \mathrm{~m}-1788 \mathrm{~m}$ and $2115 \mathrm{~m}-2134$ $\mathrm{m}$. This was corroborated by the composite plot from biostratigraphical data and wireline log signatures which also indicated the presence of Maximum Flooding Surface at about $2728 \mathrm{~m}$ (MFS 1) and $1797 \mathrm{~m}$ (MFS 2) depths (Olure-1 well). The presence of a Sequence Boundary at depth of $2602 \mathrm{~m}$ (SB 1) was also identified which also corroborated with the depth interval where there appeared to be the least abundance and diversity of species as shown in the biostratigraphic data 
of the well. The deposition environmental studies suggested an inner neritic to coastal deltaic setting for Olure-1 and Abigboro-1 wells. The presence of some diagnostic species such as Lenticulina grandis, Florilus ex. gr. costiferum, Hanzawaia concentrica, Hopkinsina bononiensis, Marginulina costata and Pseudonodosaria sp. (Olure-1 well) and Bolivina mandoroveensis, Eponides eshira, Lenticulina grandis, Lenticulina grandis, Cibicorbis inflata, Heterolepa floridana, Florilus ex. gr scaphum, Poroeponides lateralis, Uvigerina sparsicostata, Uvigerina subperegrina, Bolivina ex. gr. scalptrata, Valvulineria sp. and Epistominella pacifica (Abigboro-1 well) suggests late Oligocene - early Miocene age. A sequence stratigraphic model generated for exploration suggest the sand packages of the Lowstand Systems Tract can serve as reservoir rock while the fossiliferous shale units of the Transgressive Systems Tract could serve as the seals and source rock for hydrocarbon.

\section{References}

[1] Klett, T.R., Ahlbrandt, T.S., Schmoker, J.W. and Dolton, J.L. (1997) Ranking of the World's Oil and Gas Provinces by Known Petroleum. Vol. 6, U.S. Geological Survey Open-File Report, 97-463.

[2] Doust, H. and Omatsola, E. (1989) Niger Delta. American Association of Petroleum Geologist Bulletin, 48, 201-238.

[3] Kulke, H. (1995) Nigeria. In: Kulke, H., Ed., Regional Petroleum Geology of the World. Part II: Africa, America, Australia and Antarctica, Gebrüder Borntraeger, Berlin, 143-172.

[4] Ekweozor, C.M. and Daukoru, E.M. (1984) Petroleum Source-Bed Evaluation of the Tertiary Niger Delta. American Association of Petroleum Geologist Bulletin, 68, 390-394.

[5] Clement, E.B., Thomas, A.H. and Ibidapo, A.S. (2014) Sequence Stratigraphy Study of UNIABR Field in Northern Delta Depobelt of Niger Delta, Nigeria. Journal of Environment and Earth Science, 4, 41-52.

[6] Oloto, I.N. and Promise, W. (2014) Biostratigraphic Study and Paleoenvironmental Reconstruction of Cores from Offshore (South Western) Niger Delta, Nigeria. International Journal of Scientific \& Technology Research, 3, 279-286.

[7] Boboye, O.A. and Ademola, O.J. (2013) Late Miocene Foraminiferal and Palynologic Events of Oborduka-1 Well, Deep Offshore, Niger Delta, Nigerian. Middle-East Journal of Scientific Research, 13, 856-864.

[8] Boboye, O.A. and Adeleye, A.M. (2009) High Resolution Biostratigraphy of Early Pliocene to Late Miocene Calcareous Nannoplankton and Foraminiferal, Deep Offshore Niger Delta, Nigeria. European Journal of Science Research, 34, 308-325.

[9] Van Hoeken-Klinkenberg, P.M.J. (1966) Maastrichtian, Paleocene and Eocene Pollen and Spores from Nigeria. Leidse Geologic Model, 38, 37-38.

[10] Wade, M.E. (1964) Application of Lineage Concepts Biostratigraphic Zoning Based on Planktonic Foraminiferal. Micropalaeontology, 1-2, 1-394.

[11] Ozumba, M.B. and Amajor, L.C. (1999) Evolutionary Relationships in Some Benthic Foraminifera of the Middle to Late Miocene, Niger Delta. Nigeria Association of Petroleum Explorationists, 14, 157-167.

[12] Boboye, O.A. and Fowora, O. (2007) Calcareous Nannofossil Biostratigraphic Study 
of Well XH-1 Deep Offshore, Niger Delta, Nigeria. Journal of Mining and Geology, 43, 1-14. https://doi.org/10.4314/jmg.v43i1.47903

[13] Perch-Nielsen, K. (1967) Nannofossilien aus dem Eozan von Danemark. Eclogae Geologicae Helvetiae, 60, 19-32.

[14] Blow, W.H. (1969) Late Middle Eocene to Recent Planktonic Foraminiferal Biostratigraphy. In: Bronnimann, P. and Renz, H.H., Eds., Proceedings of the 1 st International Conference on Planktonic Microfossils, Geneva, Vol. 1, 199-422.

[15] Blow, W.H. (1979) The Cainozoic Globigerinidae. A Study of the Morphology, Taxonomy, Evolutionary Relationship and the Stratigraphical Distribution of Some Globigerinidae (Mainly Globigerinacea). E.J. Brill, Leiden, 3, 1413.

[16] Bolli, H.M and Saunders, J.B. (1985) Oligocene and Holocene Low Latitude Planktic Foraminifera. In: Bolli, H.M., Saunders, J.B. and Perch-Nielsen, K., Eds., Planktonic Stratigraphy, Cambridge University Press, Cambridge, Earth Science Series, 155262.

[17] Germeraad, J.H., Hopping, C.A. and Muller, J. (1968) Palynology of Tertiary Sediments from Tropical Areas. Review of Palaeobotany and Palynology, 6, 189-348.

[18] Evamy, B.D., Haremboure, R.K., Knapp, W.A., Molloy, F.A. and Rowlands, P.H. (1978) Hydrocarbon Habitat of Tertiary Niger Delta. American Association of Petroleum Geologist Bulletin, 62, 1-39.

[19] Martini, E. (1971) Standard Tertiary and Quaternary Calcareous Nannoplankton Zonation. Proceedings of the 2nd Planktonic Conference, Roma, 739-785.

Submit or recommend next manuscript to SCIRP and we will provide best service for you:

Accepting pre-submission inquiries through Email, Facebook, LinkedIn, Twitter, etc. A wide selection of journals (inclusive of 9 subjects, more than 200 journals)

Providing 24-hour high-quality service

User-friendly online submission system

Fair and swift peer-review system

Efficient typesetting and proofreading procedure

Display of the result of downloads and visits, as well as the number of cited articles

Maximum dissemination of your research work

Submit your manuscript at: http://papersubmission.scirp.org/

Or contact ojg@scirp.org 